\title{
Amphibians and reptiles from Floresta Nacional de Pau-Rosa, Amazonas, Brazil: an important protected area at the heart of Amazonia
}

\author{
Gisele Cassundé FERREIRA ${ }^{1,2^{*}}$, Marcelo J. STURARO², Pedro L. Vieira PELOSO² \\ 1 Universidade Federal do Pará, Instituto de Ciências Biológicas, Rua Augusto Correia, 1 Campus Básico, Belém, Pará, Brazil, CEP 66075-110. \\ 2 Museu Paraense Emílio Goeldi, CZ0, Sala 20, Av. Perimetral, 1901, Terra Firme, Belém, Pará, Brazil, CEP 66077-830. \\ * Corresponding author: gi.cassunde@hotmail.com
}

\section{ABSTRACT}

Amazonia harbors the largest and most diverse tropical forest in the world, but knowledge about the species diversity of the region is still far from ideal. Given this low level of faunal and floral knowledge, we present an annotated list of the species of amphibians and reptiles found in Floresta Nacional do Pau-Rosa (FNPR), along the Rio Paraconi, municipality of Maués, state of Amazonas, Brazil. Herpetofauna of the FNPR was sampled with pitfall traps, active search and occasional encounters from February 18 to March 28, 2009. A total of 270 specimens were collected, representing 39 species of amphibians and 24 species of reptiles. At least seven of the species collected at FNPR represented, at the time, unnamed taxa (four of which have now been named). The number of taxa collected and the high number of unnamed taxa highlight the importance of this area in terms of biodiversity and as a priority for conservation. We also discuss about the amphibian diversity in Amazonia.

KEYWORDS: Amazon Basin, biodiversity, checklist, conservation, herpetology

\section{Anfíbios e répteis da Floresta Nacional de Pau-Rosa, Amazonas, Brasil: uma importante área protegida no coração da Amazônia}

\section{RESUMO}

A Amazônia engloba a maior e mais diversa floresta tropical do mundo, mas o conhecimento sobre a diversidade de espécies da região ainda está longe do ideal. Apresentamos aqui uma lista comentada das espécies de anfíbios e répteis encontradas na Floresta Nacional de Pau-Rosa (FNPR), ao longo do Rio Paraconi, município de Maués, estado do Amazonas, Brasil. Espécimes da FNPR foram coletados com armadilhas de queda, busca ativa e encontros ocasionais de 18 fevereiro a 28 março de 2009. Um total de 270 espécimes foram coletados, o que representou 39 espécies de anfíbios e 24 espécies de répteis. Pelo menos sete das espécies coletadas na FNPR representaram, na época, táxons sem nome (quatro dos quais já foram nomeados). O número de exemplares recolhidos e o elevado número de táxons destaca a importância desta área em termos de biodiversidade e como uma área prioritária para a conservação. Nós também discutimos a diversidade de anfíbios na Amazônia.

PALAVRAS-CHAVE: Bacia Amazônica, biodiversidade, inventário, conservação, herpetologia 


\section{INTRODUCTION}

Amazonia is the largest and most diverse tropical forest in the world, housing a great number of species of animals and plants, many of which are endemic to this biome. It is well established that the knowledge of Amazonian species diversity is still far from ideal. Among groups that deserve much greater attention than currently given are amphibians and reptiles. Recent studies report that Brazil is home to 1026 species of amphibians and 808 species and subspecies of reptiles (Segalla et al. 2014), and that within the Brazilian Amazonia, there are 331 amphibian and 310 reptile species (Ávila-Pires 2016a,b; Hoogmoed 2016; Prudente 2016). However, due to the lack of basic studies on Amazonian biodiversity, it is extremely difficult to estimate how many of the species of amphibians and reptiles actually occur in Amazonia. Information on the composition and structure of populations of amphibians and reptiles in Amazonia is scarce and usually concentrated close to areas of higher human occupation or with easy access by roads or rivers (e.g., Azevedo-Ramos and Galatti 2002; Vogt et al. 2007). In consequence, and due to the vast territory and difficulties with access, many areas in Amazonia are still poorly known in terms of their herpetofauna (Ávila-Pires et al. 2010; Peloso 2010).

The region between the Madeira and Tapajós rivers is commonly referred to as the Rondônia Area of Endemism (RAE) (Cracraft 1985; Silva et al. 2002). This is one of the most threatened and least scientifically explored areas within the Brazilian Amazon (Silva et al. 2002; Cohn-Haft et al. 2007; Fernandes 2013). Rampant deforestation and recent human settlement and expansion are the main threats to the forests in the RAE. The RAE covers some $675.454 \mathrm{~km}^{2}$ (with most of its area in Brazil), and includes several protected areas (Silva $e t$ al. 2005). Among these is the Floresta Nacional de Pau-Rosa (FNPR), Maués municipality, Amazonas State, northern Brazil. The FNPR was officially established in 2001.

Given the very limited knowledge about the faunal and floral composition of the FNPR (Dantas et al. 2011), a multidisciplinary scientific expedition was organized to the area in 2009 to conduct biodiversity surveys of the species of animals and plants occurring in the region. To date, the only checklist published for FNPR is the list of bird species, which reported a remarkable diversity (269 species), even with the short duration of the expedition (Dantas et al. 2011). Herein, we present the results of the amphibian and reptile inventories, conducted concomitantly with the bird inventory reported by Dantas et al. (2011).

\section{MATERIALS AND METHODS}

\section{Study area}

The Floresta Nacional de Pau-Rosa (FNPR) is a federally protected area in Amazonian Brazil established on August 7, 2001. The area is managed for sustainable use and covers a total of 827,877 hectares, in the Municipality of Maués, eastern Amazonas State. The reserve is located in the municipalities of Nova Olinda do Norte and Borba. The FNPR lies within the Rio Tapajós/Rio Madeira interfluve and it is part of the Rondônia Area of Endemism (sensu Cracraft 1985; Silva et al. 2002). Despite the relatively good state of preservation of the area, FNPR has suffered severely from the expansion of illegal logging (ICMBio 2015). The climate is Equatorial, with predominance of Subtype Am (following the classification of Köppen 1918), characterized by high rainfall and a very short dry period, so that the area has characteristics typical of rainforest. The average annual temperature is $26^{\circ} \mathrm{C}$. All climatological and geographical data on the FNPR were obtained from Instituto Chico Mendes de Conservação da Biodiversidade (ICMBio 2015).

\section{Collection and analysis of data}

Samples were collected along the Paraconi river, concentrating on a few sampling points in the communities of Bragança, Cacoal, Caiaué, Fortaleza, Osório, Santa Teresa, São Pedro and São Tomé (Figure 1; Table 1), between February 18 and March 4, 2009. Samples were collected mostly with pitfall traps (PFT), this being a largely successful and effective method to capture amphibians and reptiles (Mengak and Guynn 1987; Ribeiro-Júnior et al. 2011).

Table 1. Sampling points in the Floresta Nacional de Pau-Rosa, municipality of Maués, state of Amazonas, Brazil, with geographic coordinates. PFT = pitfall traps; $A S=$ active search; $O E=$ occasional encounters.

\begin{tabular}{lcc}
\hline Locality & Geographic Coordinates & Sampling Method \\
\hline Comunidade Bragança, Rio Paraconi & $-3.947117077,-58.45627081$ & PFT; AS \\
Comunidade Cacoal, Rio Paraconi & $-3,918912308,-58.46041046$ & AS \\
Comunidade Caiaué, Rio Paraconi, Igarapé Tabacal & $-3,998015681,-58.41517861$ & AS; OE \\
Comunidade Fortaleza, Rio Paraconi & $-3,968860488,-58.4295436$ & AS \\
Comunidade Osório, Rio Paraconi, Igarapé afluente do Igarapé das Pedras & $-3,817108395,-58.28726775$ & AS; OE \\
Comunidade Santa Teresa, Rio Paraconi & $-3,888415759,-58.34487649$ & AS; OE \\
Comunidade São Pedro, Rio Arariú, Lago Paraíba & $-3,725969279,-58.30264217$ & OE \\
Comunidade São Tomé, Rio Paraconi, Igarapé Tabacal & $-3.907387024,-58.40220879$ & PFT; AS; OE \\
\hline
\end{tabular}




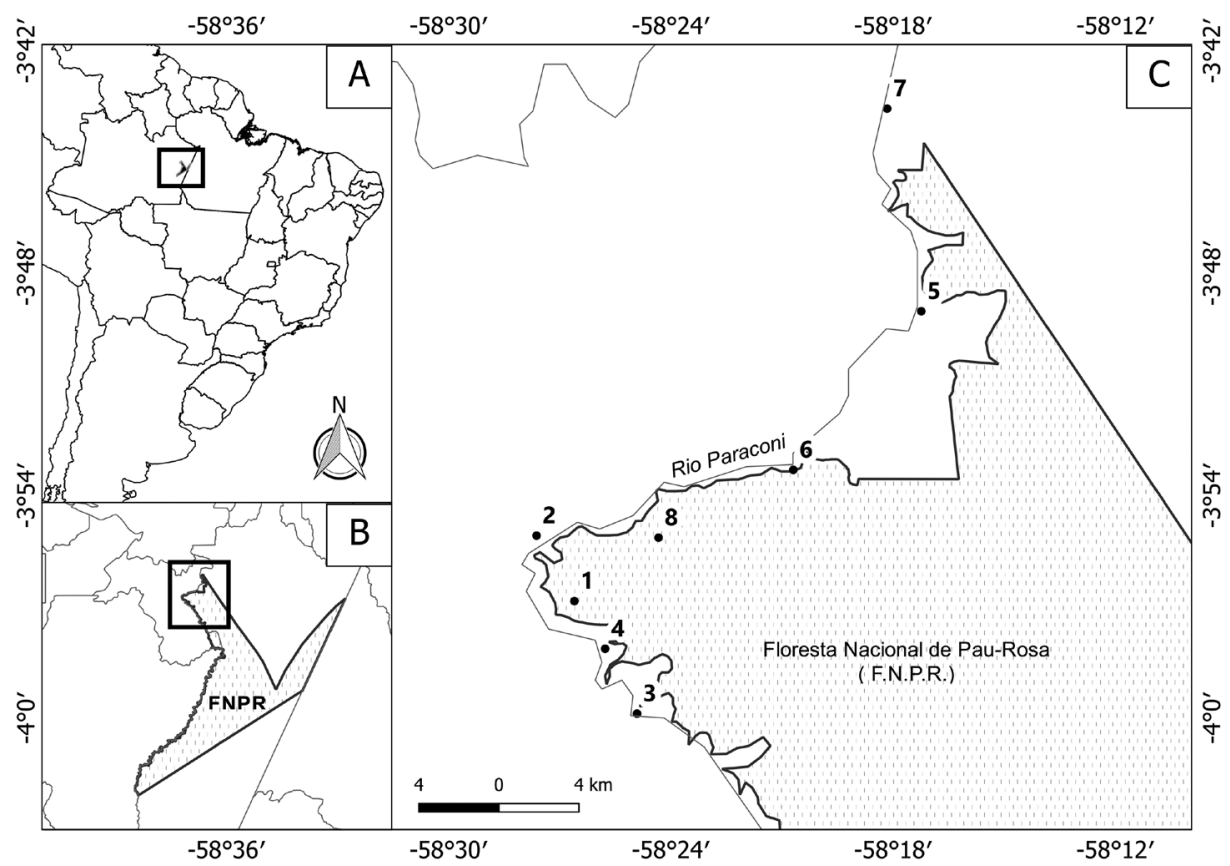

Figure 1. Study area. (A) and (B) show the exact location and limits of Floresta Nacional de Pau-Rosa (FNPR), in the municipality of Maués, state of Amazonas, Brazil. The points shown in (C) represent the sampling points within FNPR: Bragança (1), Cacoal (2), Caiaué (3), Fortaleza (4), Osório (5), Santa Teresa (6), São Pedro (7) and São Tomé (8).

Pitfall traps were installed in stations consisting of four buckets each (each bucket with 60 liters capacity), arranged in a radial pattern (explained in detail in Cechin and Martins 2000). Each station consisted of one central bucket and one bucket at each endpoint, with terminal buckets separated from the middle bucket by a $50 \mathrm{~cm}$ high plastic drift fence running for eight meters. Twenty PFT stations were installed at two distinct points, with ten stations at each sampling point: Community of Bragança; and Community of São Tomé (see Table 1). The installed PTF stations were separated by $150 \mathrm{~m}$.

We also spent 150 hours in active search (AS) during days and nights. During AS, we inspected potentially suitable microhabitats for amphibians and reptiles (e.g., burrows, fallen trunks, leaf litter, potholes, ponds, rivulets, floating aquatic vegetation, trees, treeholes). Some specimens were collected and brought to us by third parties, or were occasional encounters (OE) by one of us when not actively searching.

Collected specimens were killed with a lethal dose of $2 \%$ lidocaine. Each specimen received a unique field identification number $($ acronym $=$ FPR) and, for most specimens, we collected a small sample of muscle and/or liver, which was fixed in $100 \%$ ethanol, for future genetic studies. All specimens were fixed in a $4 \%$ formalin solution and then preserved in a $70 \%$ ethanol solution. All collected specimens and tissue subsamples were incorporated to Coleção Herpetológica Osvaldo Rodrigues da Cunha, deposited at Museu Paraense Emílio Goeldi, Belém, state of Pará, Brazil (MPEG).
The study and collection of specimens at FNPR was authorized by Instituto Chico Mendes de Conservação da Biodiversidade (permit number SISBIO 18087-1).

\section{RESULTS}

During the scientific expedition to FNPR, we collected a total of 270 specimens pertaining to the following taxonomic groups: 37 species of Anura (18 genera, six families), two species of Gymnophiona (two genera, two families), one species of Crocodylia, 12 species of Squamata (lizards) (11 genera, five families), one species of Testudines and ten species of Squamata (snakes) (ten genera, three families). The complete list of the species sampled in our study is given in Tables 2 (amphibians) and 3 (reptiles).: The voucher numbers of the collection material is available in the Supplementary Material (Annex S1). At least seven of the species (six anurans and one lizard) collected at FNPR represented, at the time, unnamed taxa (four of which have been named since then).

Among the eight sampling points, the Bragança and Sáo Tomé were the best represented in the collection, with 135 and 109 collected specimens, respectively-collectively accounting for more than $90 \%$ of the total specimens. This disproportion is certainly a consequence of the fact that only these two sites were sampled with PFT. Of the 270 specimens collected overall, 146 were trapped and four were found next to the buckets or over the plastic fences. 
Table 2. List of species of Amphibia (Anura and Gymnophiona) of Floresta Nacional de Pau-Rosa, municipality of Maués, state of Amazonas, Brazil. PFT $=$ pitfall traps; $\mathrm{AS}=$ active search; $\mathrm{OE}=$ occasionally encountered.

\begin{tabular}{|c|c|c|}
\hline Taxon & $\begin{array}{l}\text { Sampling } \\
\text { Method }\end{array}$ & Figure \\
\hline \multicolumn{3}{|l|}{ ORDER ANURA } \\
\hline \multicolumn{3}{|l|}{ AROMOBATIDAE } \\
\hline Allobates femoralis (Boulenger, 1884) & PFT & $2 \mathrm{~A}$ \\
\hline Allobates grillisimilis Simões et al. 2014 & PFT; AS & \\
\hline Allobates masniger (Morales, 2002) & PFT; AS & $2 \mathrm{~B}$ \\
\hline \multicolumn{3}{|l|}{ BUFONIDAE } \\
\hline Amazophrynella bokermanni (Izecksohn, 1994) & PFT; AS & $2 \mathrm{C}$ \\
\hline Rhinella gr. margaritifera & PFT; AS & $2 \mathrm{D}$ \\
\hline Rhinella marina (Linnaeus, 1758) & PFT; AS & \\
\hline \multicolumn{3}{|l|}{ CERATOPHRYIDAE } \\
\hline Ceratophrys cornuta (Linnaeus, 1758) & PFT & $2 \mathrm{E}$ \\
\hline \multicolumn{3}{|l|}{ CRAUGASTORIDAE } \\
\hline Pristimantis fenestratus (Steindachner, 1864) & $\mathrm{AS} ; \mathrm{OE}$ & $2 \mathrm{~F}$ \\
\hline Pristimantis sp. 1 & AS & $2 \mathrm{G}$ \\
\hline \multicolumn{3}{|l|}{ HYLIDAE } \\
\hline Boana cinerascens (Spix, 1824) & AS & $2 \mathrm{H}$ \\
\hline Boana wavrini (Parker, 1936) & AS & 21 \\
\hline Dendropsophus mapinguari Peloso et al. 2016 & AS & $2 \mathrm{~J}$ \\
\hline Dendropsophus minusculus (Rivero, 1971) & AS & $2 \mathrm{~K}$ \\
\hline Dendropsophus minutus (Peters, 1872) & AS & $2 \mathrm{~L}$ \\
\hline Dendropsophus ozzyi Orrico et al. 2014 & AS & $2 \mathrm{M}$ \\
\hline Dendropsophus schubarti Bokermann, 1952 & AS & $2 \mathrm{~N}$ \\
\hline Dendropsophus sp. 1 & AS & 20 \\
\hline Osteocephalus taurinus Steindachner, 1862 & AS & $3 \mathrm{~A}$ \\
\hline Scinax garbei (Miranda-Ribeiro, 1926) & $\mathrm{OE}$ & $3 \mathrm{~B}$ \\
\hline Scinax sateremawe Sturaro \& Peloso, 2014 & AS & $3 C$ \\
\hline Scinax sp. 1 & AS & $3 \mathrm{D}$ \\
\hline Scinax sp. 2 & AS & $3 \mathrm{E}$ \\
\hline \multicolumn{3}{|l|}{ PHYLLOMEDUSIDAE } \\
\hline Phyllomedusa vaillantii Boulenger, 1882 & AS & $3 F$ \\
\hline Pithecopus hypochondrialis (Daudin, 1800) & AS & $3 G$ \\
\hline \multicolumn{3}{|l|}{ LEPTODACTYLIDAE } \\
\hline Adenomera sp. & PFT; AS & $3 \mathrm{H}$ \\
\hline Hydrolaetare sp. & AS & \\
\hline Leptodactylus knudseni Heyer, 1972 & AS & \\
\hline Leptodactylus mystaceus (Spix, 1824) & PFT & \\
\hline Leptodactylus pentadactylus (Laurenti, 1768) & PFT & \\
\hline Leptodactylus petersii (Steindacher, 1864) & AS & 31 \\
\hline Leptodactylus sp.1 & PFT & \\
\hline Phyzelaphryne miriamae Heyer, 1977 & PFT; AS & 3J \\
\hline \multicolumn{3}{|l|}{ MICROHYLIDAE } \\
\hline Chiasmocleis avilapiresae Peloso \& Sturaro, 2008 & PFT; AS & $3 \mathrm{~K}$ \\
\hline Chiasmocleis bassleri Dunn, 1949 & PFT; AS & $3 \mathrm{~L}$ \\
\hline Chiasmocleis hudsoni Parker, 1940 & AS & $3 \mathrm{M}$ \\
\hline Ctenophryne geayi Mocquard, 1904 & PFT; AS & $3 N$ \\
\hline Hamptophryne boliviana (Parker, 1927) & PFT; AS & 30 \\
\hline
\end{tabular}

Table 2. Continuation.

\begin{tabular}{lcc}
\hline Taxon & $\begin{array}{c}\text { Sampling } \\
\text { Method }\end{array}$ & Figure \\
\hline ORDER GYMNOPHIONA & & \\
CAECILIIDAE & & \\
$\begin{array}{l}\text { Caecilia gracilis Shaw, } 1802 \\
\text { TYPHLONECTIDAE }\end{array}$ & PFT & $4 \mathrm{~A}$ \\
$\begin{array}{l}\text { Typhlonectes compressicauda (Duméril \& Bibron, } \\
\text { 1841) }\end{array}$ & OE \\
\hline
\end{tabular}

Table 3. List of species of Reptilia (Crocodylia, Squamata and Testudinata) of Floresta Nacional de Pau-Rosa, municipality of Maués, State of Amazonas, Brazil. PFT = pitfall traps; $\mathrm{AS}=$ active search; $\mathrm{OE}=$ occasionally encountered.

\begin{tabular}{|c|c|c|}
\hline Taxon & Collection method & Figure \\
\hline \multicolumn{3}{|l|}{ ORDER CROCODYLIA } \\
\hline \multicolumn{3}{|l|}{ ALLIGATORIDAE } \\
\hline Paleosuchus palpebrosus (Cuvier, 1807) & AS & \\
\hline \multicolumn{3}{|l|}{ ORDER SQUAMATA (LIZARD) } \\
\hline \multicolumn{3}{|l|}{ GYMNOPHTHALMIDAE } \\
\hline Cercosaura sp. & PFT; AS & 4D \\
\hline Iphisa elegans Gray, 1851 & PFT; AS & $4 \mathrm{E}$ \\
\hline Loxopholis osvaldoi Avila-Pires, 1995 & PFT; AS & $4 \mathrm{~F}$ \\
\hline \multicolumn{3}{|l|}{ IGUANIDAE } \\
\hline Plica umbra (Linnaeus, 1758) & PFT & $4 \mathrm{G}$ \\
\hline Uranoscodon superciliosus (Linnaeus, 1758) & AS & $4 \mathrm{H}$ \\
\hline \multicolumn{3}{|l|}{ POLYCHROTIDAE } \\
\hline Norops fuscoauratus D’Orbigny, 1837 & PFT & 41 \\
\hline Norops tandai Avila-Pires, 1995 & PFT & $4 \mathrm{~J}$ \\
\hline \multicolumn{3}{|l|}{ SPHAERODACTYLIDAE } \\
\hline Chatogekko amazonicus (Andersson, 1918) & PFT; AS & \\
\hline Gonatodes humeralis (Guichenot, 1855) & PFT & $4 \mathrm{~K}$ \\
\hline Lepidoblepharis heyerorum Vanzolini, 1978 & PFT & $4 \mathrm{~L}$ \\
\hline \multicolumn{3}{|l|}{ TEIIDAE } \\
\hline Ameiva ameiva (Linnaeus, 1758) & AS & \\
\hline Kentropyx calcarata Spix, 1825 & PFT & $4 \mathrm{M}$ \\
\hline \multicolumn{3}{|l|}{ ORDER SQUAMATA (SNAKE) } \\
\hline \multicolumn{3}{|l|}{ BOIDAE } \\
\hline Boa constrictor Linnaeus, 1758 & $\mathrm{AS} ; \mathrm{OE}$ & $4 \mathrm{~N}$ \\
\hline Corallus hortulanus (Linnaeus, 1758) & AS & 40 \\
\hline Eunectes murinus (Linnaeus, 1758) & $\mathrm{OE}$ & \\
\hline \multicolumn{3}{|l|}{ COLUBRIDAE } \\
\hline Atractus elaps (Günther, 1858) & PFT & $5 A$ \\
\hline Erythrolamprus oligolepis (Boulenger, 1905) & PFT & $5 B$ \\
\hline Imantodes lentiferus (Cope, 1894) & AS & $5 C$ \\
\hline Taeniophalus occiptalis (Jan, 1863) & PFT & $5 \mathrm{D}$ \\
\hline Tantilla melanocephala (Linnaeus, 1758) & PFT & $5 \mathrm{E}$ \\
\hline Xenopholis scalaris (Wucherer, 1861) & PFT; AS & $5 F$ \\
\hline \multicolumn{3}{|l|}{ VIPERIDAE } \\
\hline Bothrops atrox (Linnaeus, 1758) & AS & \\
\hline \multicolumn{3}{|l|}{ ORDER TESTUDINES } \\
\hline \multicolumn{3}{|l|}{ TESTUDINIDAE } \\
\hline Chelonoidis denticulata (Linnaeus, 1766) & AS & $4 \mathrm{~B}, 4 \mathrm{C}$ \\
\hline
\end{tabular}




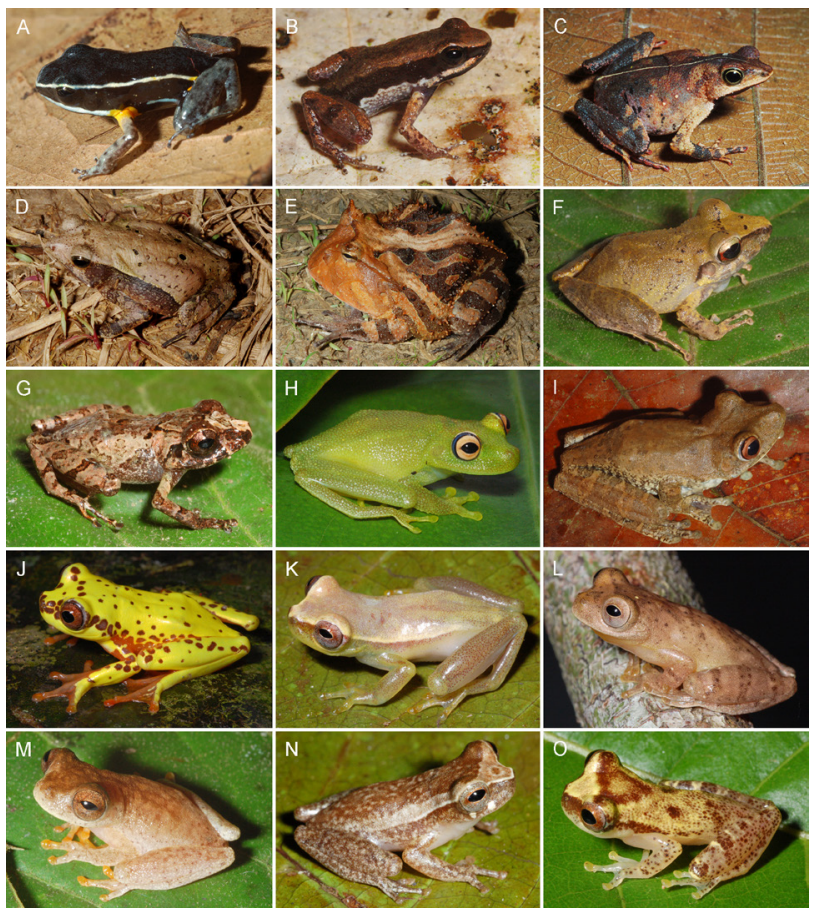

Figure 2. Photos of some of the species found in the Floresta Nacional de Pau-Rosa, municipality of Maués, state of Amazonas, Brazil. (A) Allobates femoralis, (B) Allobates masniger, (C) Amazophrynella bokermanni, (D) Rhinella gr. margaritifera, (E) Ceratophrys cornuta, (F) Pristimantis fenestratus, (G) Pristimantis sp. 1, (H), Boana cinerascens, (I), Boana wavrini, (J) Dendropsophus mapinguari, (K) Dendropsophus minuscuslus, (L) Dendropsophus minutus, (M) Dendropsophus ozzyi, (N) Dendropsophus schubarti, (0) Dendropsophus sp. 1. This figure is in color in the electronic version.

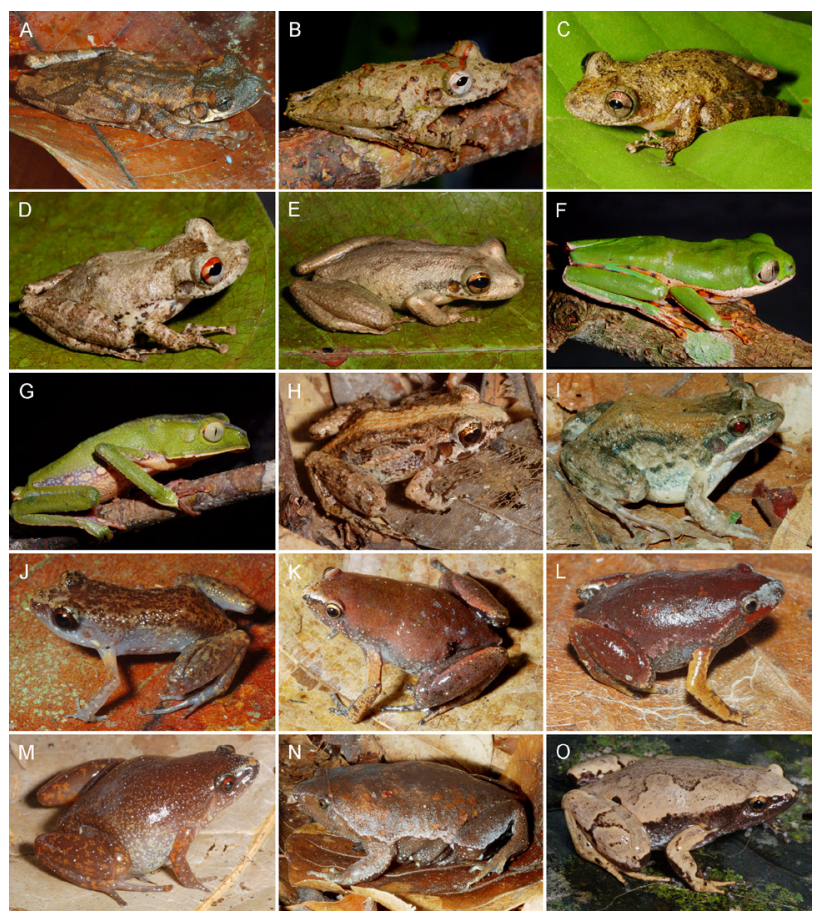

Figure 3. Photos of some of the species found in the Floresta Nacional de Pau-Rosa, municipality of Maués, state of Amazonas, Brazil. (A) Osteocephalus taurinus, (B) Scinax garbei, (C) Scinax sateremawe, (D) Scinax sp. 1, (E), Scinax sp. 2, (F) Phyllomedusa vaillanti, (G) Pithecopus hypochondrialis, (H) Adenomera sp. 1, (I) Leptodactylus petersii, (J) Phyzelaphryne miriamae, (K) Chiasmocleis avilapiresae, (L) Chiasmocleis bassleri, (M) Chiasmocleis hudsoni, (N) Ctenophryne geayi, (0) Hamptophryne boliviana. This figure is in color in the electronic version. 


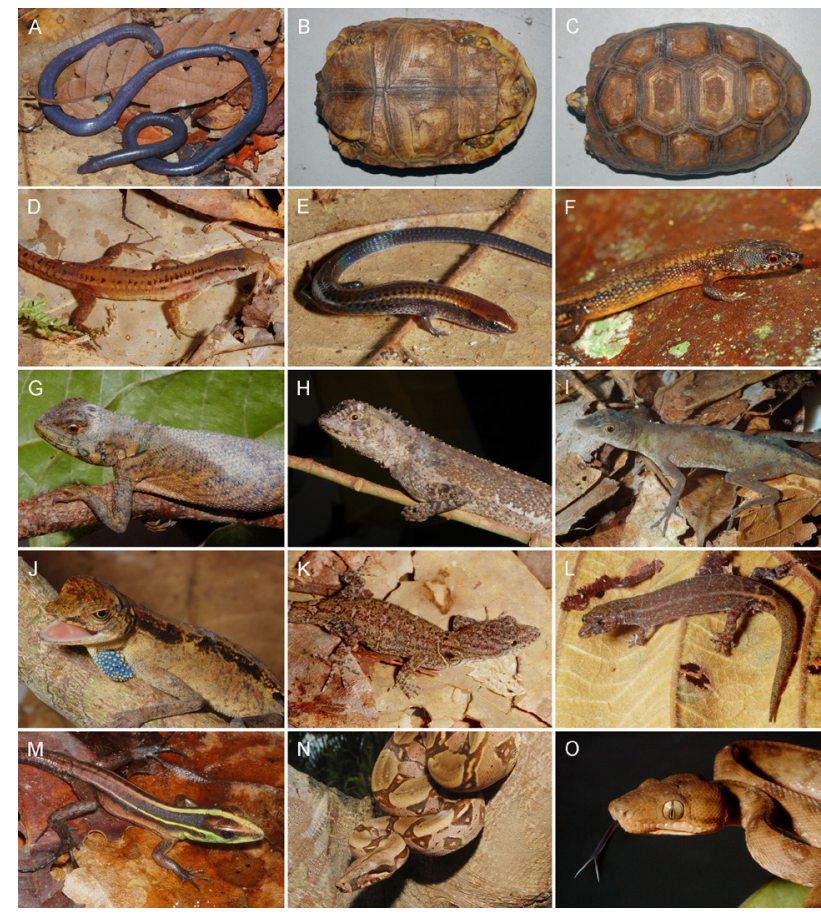

Figure 4. Photos of some of the species found in the Floresta Nacional de PauRosa, municipality of Maués, state of Amazonas, Brazil. (A) Caecilia gracilis, (B) Chelonoidis denticulata in ventral view, (C) Chelonoidis denticulata in dorsal view, (D) Cercosaura sp. (E) Iphisa elegans, (F) Loxopholis osvaldoi, (G) Plica umbra, (H) Uranoscodon superciliosus, (I) Norops fuscoauratus, (J) Norops tandai, (K) Gonatodes humeralis, (L) Lepidoblepharis heyerorum, (M) Kentropyx calcarata, (N) Boa constrictor, (0) Corallus hortulanus. This figure is in color in the electronic version.

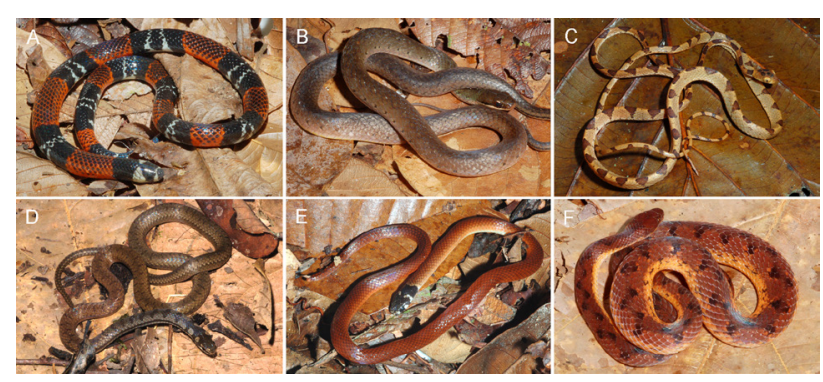

Figure 5. Photos of some of the species found in the Floresta Nacional de Pau-Rosa, municipality of Maués, state of Amazonas, Brazil. (A) Atractus elaps, (B) Erythrolamprus oligolepis, (C) Imantodes lentiferus, (D) Taeniophalus occiptalis, (E) Tantilla melanocephala, (F) Xenopholis scalaris. This figure is in color in the electronic version.

\section{DISCUSSION}

At first glance, the alpha diversity of species found in FNPR (63 species) is not very high when compared to other localities within the Amazonia lowlands (e.g., Azevedo-Ramos and Galatti 2002; Ávila-Pires et al., 2010). Nonetheless, because the inventory at FNPR was carried out in a short period of time, it is very likely that more species will be found in the area as sampling is increased. We expect that the herpetofaunal richness at FNPR to be much higher than estimated herein. Several species distributed across the Amazonian basin were not found in our inventory and are likely to be encountered once additional sampling is performed. This is particularly true for several species of snakes and lizards, which are naturally more difficult to sample in short term assessments (RibeiroJúnior et al. 2008; Fraga et al. 2014).

We recorded a very low number of species with fossorial, aquatic and semi-aquatic habits. Sampling of such species usually require a targeted sampling effort, as they can significantly increase the chances of capturing specimens of specific taxonomic groups (Ribeiro-Júnior et al. 2008). For aquatic chelonians, for example, special collection techniques, such as funnel traps and other baited aquatic traps (not used in this survey) may be required. The sampling of caecilians (Gymnophiona) is also quite complicated-they are usually found by chance, as they may exhibit partially or completely aquatic or fossorial habits (Ávila-Pires et al. 2010; Peloso 2010). Localized efforts, such as baited trapping for aquatic species, and digging for fossorial species can yield large number of individuals of this taxa (unpubl. data), whereas they are rarely sampled with the conventional techniques employed by us (PFT and visual surveys). Directed efforts will be needed to properly sample Gymnophiona taxa at FNPR.

\section{Undetermined taxa}

Azevedo-Ramos and Galatti (2002) estimated that, for Amazonian amphibians, the number of undetermined taxa (those unidentified to species level) might vary from 2-39\% of the total of sampled species in a given area. Undetermined taxa may be a consequence of one or several combined factors, including: presence of unnamed species in the sample, lack of sufficient taxonomic knowledge about a given group (e.g., species complexes), insufficient material collected (e.g., if only juveniles or larvae are collected) (Caldwell 1996; AzevedoRamos and Galatti 2002; Peloso 2010).

At FNPR the total rate of undetermined species (at the time of the expedition) was $20.6 \%$, with the majority of undetermined taxa corresponding to amphibians. Almost half of the undetermined taxa refers to unnamed species, whereas the remaining pertain to taxa to which we could not determine to the species level due to a variety of reasons. Among reptiles, the only undetermined taxon is an unnamed species of Cercosaura (Sturaro et al., 2017). Among amphibians, the rate of undetermined species was $30.8 \%$, of which half were unnamed taxa and the other half could not be identified for various reasons. 
Despite the short time of collection we collected seven new, unnamed, species (six new species of amphibians and one new species of lizard). From the time of collection (2009) to time of final submission of the manuscript (June, 2017), four of these seven taxa have been formally described and named: Allobates grillisimilis Simōes et al. 2013; Dendropsophus mapinguari Peloso et al. 2016; Dendropsophus ozzyi Orrico et al. 2014; and Scinax sateremawe Sturaro and Peloso 2014. The remaining unnamed taxa (one species of Dendropsophus, one species of Scinax and one species of Cercosaura) still await formal description.

\section{Comparisons with other Amazonian sites: how many species are there?}

The total number of amphibian species present in Amazonia is largely uncertain, with estimates ranging from 378 species of reptiles and 427 species of amphibians (Silva et al. 2005) to over 450 species of reptiles and over 1000 species of amphibians (P.L.V. Peloso unpubl. data). The pattern of distribution of these species across Amazonia is also largely debated and, due to scarcity of information, it is likely that not even a rough estimate will be available for the majority of species within the foreseeable future.

Inasmuch as many localities across the Amazon do have species lists published, studies with a comparative approach are considerably scarce. In a review of available inventories of amphibians in the Brazilian Amazon Azevedo-Ramos and Galatti (2002) reported 28 inventories and a total diversity of 163 species of amphibians. At that time, diversity of species ranged, across sites, from 18 species (Alter do Chão, Pará) to as many as 78 species (along a small section of the Rio Juruá). Since then, several additional amphibian inventories were published with similar numbers. A noteworthy exception is the presence of 109 amphibian species in the middle Rio Xingu (Vaz-Silvia et al. 2015). More recently, Ávila-Pires et al. (2010) compared the diversity of amphibians and reptiles across seven sites in the Guiana Shield region (state of Pará, north of Rio Amazonas). The same sampling effort was employed across all seven sites, and the number of taxa sampled within those areas varied from 21-36 amphibians and 26-42 reptiles (ÁvilaPires et al. 2010). Nonetheless, the diversity reported therein is low compared to other sites with similar sampling effort (Azevedo-Ramos and Galatti 2002). Species lists of reptiles across the Brazilian portion of Amazonia are scarcer than lists of amphibians, but diversity of reptiles in a single site may be as high as 150 species (Vaz-Silvia et al. 2015).

It is important to note that true differences in species richness across sites can be due to a series of factors, some of which are well known (e.g., habitat availability, climatic differences), others less so (Azevedo-Ramos and Galatti 2002; Galatti et al. 2007; Ribeiro-Júnior et al. 2008; Peloso 2010;
Ávila-Pires et al. 2010). Inasmuch as variation in diversity across sites can be due to natural causes, we are certain that conspicuous differences in species richness across sites is certainly an artifact of differential sampling effort across the different locations.

The number of reptile species sampled in our study is very low and more species will certainly be added with additional effort to survey the herpetofauna of FNPR. Although the number of species of amphibians at the FNPR is similar to that reported in many other Amazonian sites, we also think that several species were not sampled but are likely to be present in the area. Even species which are relatively common across most of the Amazon, and which do not require specific sampling effort, were not collected (e.g., the lizards Dactyloa punctata, Plica plica, the frogs Boana calcarata, B. geographica, Rhaebo guttatus, the snakes Dipsas catesbyi, Eunectes murinus, Leptodeira annulata, Mastigodryas bodaerti, Siphlophis complressus, among many others).

\section{How many species are there at FNPR?}

This first appraisal of the herpetofauna of FNPR can be considered moderately successful. The list of amphibians is satisfactory and we were able to find several unnamed species in the region. On the other hand, the reptile list is certainly far from complete and additional effort is needed for a better estimate of the species composition therein. Short-term studies are particularly ineffective for sampling the snake community at a given place (Fraga et al. 2014). Therefore, for a better estimate of terrestrial squamates at FNPR, a medium to long-term assessment is necessary to inventory the species present there. In regards to aquatic species, of both amphibians (caecilians) and reptiles (some snakes, chelonians and crocodilians), it may be also necessary to employ additional trapping techniques.

We reinforce that many places in Amazonia have never been sampled before and a huge number of species are still unknown (Peloso 2010). The rapid rates of deforestation and habitat modification pose a serious threat to many areas and species populations in the Amazon basin, and it is probably very accurate to say that a great number of species are likely to disappear from Amazonian forests before they are even discovered.

\section{CONCLUSIONS}

Our study at FNPR highlighted a high species richness in the region, even considering the short period of fieldwork. A total of 63 species of amphibians and reptiles were found, seven of them scientifically unknown at the time. The work represents a major first step to sample the herpetofaunal diversity of the area, an important protected area in Amazonas. However, we reinforce that until additional effort is made, we cannot provide 
an accurate estimate of the vertebrate species diversity at FNPR. This is, however, a reality of most Amazonian protected areas and, therefore, urgent and effective measures are needed to augment and accelerate biodiversity studies across the reserves implemented within the Amazon basin.

\section{ACKNOWLEDGMENTS}

The authors acknowledge financial support from Conselho Nacional de Desenvolvimento Científico e Tecnológico - CNPq (grant numbers 165474/2014-9 to GFC; PDJ 150279/2015-9 to MJS; 400252/2014-7 and BJT 313680/2014-0 to PLVP). We thank Conservation International, Brazil (especially T.P. Kasecker), Instituto Chico Mendes de Conservação da Biodiversidade (ICMBio), Museu Paraense Emílio Goeldi (MPEG), Instituto Nacional de Pesquisas da Amazônia (INPA), and Fundação Amazônica de Defesa da Biosfera (formerly Fundação Djalma Batista) for logistic and financial support for fieldwork at FNPR. Adriano O. Maciel, Alexandre C. Ascenso, João Carlos Lopes Costa and Victor D. G. Orrico helped with the identification of several species. A. C. Ascenso for preparing the map. MJS and PLVP thank the boat crew and fellow researchers (too many to mention) aboard the vessel "Cometa Halley" for companionship during fieldwork in the Rio Paraconi area. For help in the field, special thanks are due to Sindei Dantas, Maya Faccio and Hueliton Silveira.

\section{REFERENCES}

Ávila-Pires, T.C.S., 2016a. Censo da Biodiversidade da Amazônia Brasileira - MPEG: Lagartos (http://www.museu-goeldi.br/ censo/). Accessed on 12/09/2016.

Ávila-Pires, T.C.S., 2016b. Censo da Biodiversidade da Amazônia Brasileira - MPEG: Quelônios e Jacarés (http://www.museugoeldi.br/censo/). Accessed on 12/09/2016.

Ávila-pires, T.C.S.; Hoogmoed, M.S.; Rocha, W.A. 2010. Notes on the Vertebrates of northern Pará, Brazil: a forgotten part of the Guianan Region, I. Herpetofauna. Boletim do Museu Paraense Emilio Goeldi, 5: 13-112.

Azevedo-Ramos, C.; Galatti, U. 2002. Patterns of amphibian diversity in Brazilian Amazonia: conservation implications. Biological Conservation, 103: 103-111.

Caldwell, J.P. 1996. Diversity of Amazonian anurans: The role of systematics and phylogeny in identifying macroecological and evolutionary patterns. In: Gibson, A. C. (Ed.). Neotropical Biodiversity and Conservation. Mildred E. Mathias Botanical Garden, Los Angeles, p.73-88.

Cechin, S.Z.; Martins, M. 2000. Eficiência das armadilhas de queda (pitfall traps) em amostragens de anfíbios e répteis no Brasil. Revista Brasileira de Zoologia, 17: 729-740.

Cohn-Haft, M.; Pacheco, A.M.F.; Bechtoldt, C.L.; Torres, M.F.N.M.; Fernandes, A.M.; Sardelli, C.H.; Macêdo, I.T. 2007. Inventário ornitológico. In: Py-Daniel, L.R.; Deus; C.P.; Henriques, A.L.;
Pimpão, D.M.; Ribeiro, O.M. (Ed.). Biodiversidade do Médio Madeira: bases científicas para propostas de conservação. Insituto Nacional de Pesquisas da Amazônia, Manaus, Amazonas, p.145-178.

Cracraft, J. 1985. Historical biogeography and patterns of differentiation within the South American avifauna: areas of endemisms. Ornithological Monographs, 36: 49-84.

Dantas, S.M.; Faccio, M.S.; Lima, M.F. 2011. Avifaunal inventory of the Floresta Nacional de Pau-Rosa, Maués, state of Amazonas, Brazil. Revista Brasileira de Ornitologia, 19: 154-166.

Fernandes, A.M. 2013. Fine-scale endemism of Amazonian birds in a threatened landscape. Biodiversity and Conservation, 22: 2683-2694.

Fraga, R.; Stow, A.J.; Magnusson, W.E.; Lima, A.P. 2014. The costs of evaluating species densities and composition of snakes to assess development impacts in Amazonia. PLoS ONE, 9: e105453.

Galatti, U.; Estupiñán, R.A.; Dias, A.C.L.; Travassos, A.E.M. 2007. Anfíbios da Área de Pesquisa Ecológica do Guamá - Apeg e região de Belém, Pará. In: Gomes, J. I.; Martins, M. B.; Martins-daSilva, R. C. V.; Almeida, S. S. (Ed.). Mocambo: Diversidade e dinâmica biológica da área de pesquisa ecológica do Guamá (Apeg). Museu Paraense Emílio Goeldi/Embrapa Amazônia Oriental, Belém, Pará, p.76-95.

Hoogmoed, M., 2016. Censo da Biodiversidade da Amazônia Brasileira - MPEG: Anfíbios (http://www.museu-goeldi.br/ censo/). Accessed on 12/09/2016.

Instituto Chico Mendes de Conservação da Biodiversidade (ICMBio), 2015. Unidades de Conservaçáo da Amazonia: Flona de Pau Rosa (http:/www.icmbio.gov.br/portal/unidadesdeconservacao/ biomas-brasileiros/amazonia/unidades-de-conservacaoamazonia/1889-flona-de-pau-rosa). Accessed on 17/10/2015.

Köppen, W. 1918. Klassifikation der klimate nach temperatur, Niederschlag und Jahreslauf. Petermanns geographische mitteilungen, 64: 193-203.

Mengak, M.T.; Guynn Junior, D.C. 1987. Pitfall and snap traps for sampling small mammals and herpetofauna. American Midland Naturalist Journal, 118: 284-288.

Orrico, V.G.D.; Peloso, P.L.V.; Sturaro, M.J.; Silva-Filho, H.F.; Neckel-Oliveira, S.; Gordo, M.; Faivovich, J.; Haddad, C.F.B. 2014. A new "bat-voiced" species of Dendropsophus Fitzinger, 1843 (Anura, Hylidae) from the Amazon Basin, Brazil. Zootaxa, 3881: 341-361.

Peloso, P.L.V. 2010. A safe place for amphibians? A cautionary tale on the taxonomy and conservation of frogs, caecilians, and salamanders in the Brazilian Amazonia. Zoologia, 27: 667-673.

Peloso, P.L.V.; Orrico, V.G.D.; Haddad, C.F.B.; Lima-Filho, G.R.; Sturaro, M.J. 2016. A new species of clown tree frog, Dendropsophus leucophyllatus species group, from Amazonia (Anura, Hylidae). South American Journal of Herpetology, 11: 66-80.

Prudente, A.L.C., 2016. Censo da Biodiversidade da Amazônia Brasileira - MPEG: Serpentes, (http://www.museu-goeldi.br/ censo/). Accessed on 12/09/2016. 
Ribeiro-Júnior, M.A.; Rossi, R.V.; Miranda, C.L.; Ávila-Pires, T.C.S. 2011. Influence of pitfall trap size and design on herpetofauna and small mammal studies in a Neotropical Forest. Zoologia, 28: 80-91.

Ribeiro-Júnior, M.A.; Gardner, T.A.; Ávila-Pires, T.C.S. 2008. Evaluating the effectiveness of herpetofaunal sampling techniques across a gradient of habitat change in a Tropical forest landscape. Journal of Herpetology, 42: 733-749.

Segalla, M.V.; Caramaschi, U.; Cruz, C.A.G.; Grant, T.; Haddad, C.F.B.; Langone, J.B.; Garcia, P.C.A. 20 I4. Brazilian amphibians: list of species. Herpetologia Brasileira, 3: 37-48.

Silva, J.M.C.; Rylands, A.B.; Fonseca, G.A.B. 2005. The fate of the Amazonian areas of endemism. Conservation Biology, 19: 689-694.

Silva, J.M.C.; Novaes, F.C.; Oren, D.C. 2002. Differentiation of Xiphocolaptes (Dendrocolaptidae) across the river Xingu, Brazilian Amazonia: recognition of a new phylogenetic species and biogegraphic implications. Bulletin of the British Ornithologist, 122: 185-194.

Simões, P.I.; Sturaro, M.J.; Peloso, P.L.V.; Lima, A.P. 2013. A new diminutive species of Allobates Zimmermann and Zimmermann, 1988 (Anura, Aromobatidae) from the northwestern Rio Madeira-Rio Tapajós interfluve, Amazonas, Brazil. Zootaxa, 3609: 251-273.

Sturaro, M.J.; Peloso, P.L.V. 2014. A new species of Scinax Wagler, 1830 (Anura: Hylidae) from the middle Amazon River basin, Brazil. Papéis Avulsos de Zoologia, 54: 9-23.

Sturaro, M.J.; Ávila-Pires, T.C.; Rodrigues, M.T. 2015. Molecular phylogenetic diversity in the widespread lizard Cercosaura ocellata (Reptilia: Gymnophthalmidae) in South America. Systematics and Biodiversity, 2017: 1-9.
Vaz-Silva, W.; Oliveira, R.M.; Gonzaga, A.F.N.; Pinto, K.C.; Poli, C.F.; Bilce, T.M.; et al. 2015. Contributions to the knowledge of amphibians and reptiles from Volta Grande do Xingu, northern Brazil. Brazilian Journal of Biology, 75: 205-218.

Vogt, R.C.; Ferrara, C.R.; Bernhard, R.; Carvalho, V.T.; Balensiefer, D.C.; Bonora, L.; Novelle, S.M.H. 2007. Herpetofauna. In: Py-Daniel, L.R.; Deus, C.P.; Henriques, A.L.; Pimpão D.M.; Ribeiro, O.M. (Ed.). Biodiversidade do Médio Madeira: Bases cientificas para propostas de conservação. Instituto Nacional de Pesquisas na Amazônia, Manaus, Amazonas, p.127-143.

Received: 28/12/2016

Accepted: 13/06/2017

\section{SUPPLEMENTARY MATERIAL}

(only available in the electronic version)

FERREIRA et al. Amphibians and reptiles from Floresta Nacional de Pau-Rosa, Amazonas, Brazil: an important protected area at the heart of the Amazon.

Annex 1. Voucher numbers of the specimens from the herpetological survey of Floresta Nacional de Pau Rosa (Amazonas, Brazil) deposited in the herpetological collection (Coleção Herpetológica Osvaldo Rodrigues da Cunha) of Museu Paraense Emílio Goeldi (Pará, Brazil) (MPEG). 
